UDC 33+005]:004

DOI: https://doi.org/10.30839/2072-7941.2019.177758

\title{
FORMATION OF THE CONCEPT OF DIGITAL ECONOMY AND DIGITAL MANAGEMENT IN THE CONDITIONS OF NEW TECHNOLOGICAL BREAKS
}

\author{
(C) CHEREP, A. V. \\ Zaporizhzhya national University (Zaporizhzhia, Ukraine) \\ E-mail: cherep.av.znu@gmail.com, ORCID: 0000-0001-5253-7481 \\ (C) ANDRIUKAITIENE, REGINA \\ Marijampole college (Marijampole, Lithuania) \\ E-mail: regina.andriukaitiene@ gmail.com, ORCID: 0000-0002-0691-7333 \\ (C) VORONKOVA, V. H. \\ Engineering institute of Zaporizhzhya national University (Zaporizhzhia, Ukraine) \\ E-mail: valentinavoronkova236@ gmail.com, ORCID: 0000-0002-0719-1546 \\ C) OLEKSENKO, R. I. \\ Tavria State Agrotechnological University (Melitopol, Ukraine) \\ E-mail: roman.xdsl@ukr.net, ORCID iD : 0000-0002-2171-514X
}

\begin{abstract}
The relevance of this topic is due to the fact that new processes of informatization of society are unfolding in the conditions of new technological breakthroughs, which requires the formation of the concept of digital economy and digital management as components of the creation of an ecologically balanced and socially oriented economy, which aims at increasing the well-being of the population and improving the ecology of the population. The purpose of the study is to conceptualize the digital economy and digital management in the face of new technological breakthroughs as a factor in the emergence of an environmentally balanced and socially-oriented economy, as one of the biggest challenges facing developed countries is sustainable unemployment, growing property inequality, rapid climate change and stochasticity (asymmetry) of information. An analysis of the latest research and publications that address this issue. In the works of Maxton Graham and Randers Joergen "In search of prosperity. Managing Economic Development for Reducing Unemployment and Climate Change "(Kyiv: Pabulum, 2017). In the second half of the twentieth century evidence has emerged of the exhaustion of global natural resources and the limited assimilation capabilities of the planetary ecosystem. The revolutionary work of the new vision was the first report by the Roman Club "Limits of Growth" (1972) by Donnelly and Dennis Meadows and Jorgen Randers, which forced them to reflect on the physical limits of human growth. "The limits of growth. 30 Years Later" is an updated study based on new data on trends in the development of human civilization, improvements in the model and methodology of system dynamics and modern computer capabilities. Scientific novelty of the research is the identification of problems of interaction of the person, society, information in the conditions of new technological breakthroughs and conditions of overcoming the problems of stochastic information that contribute to the formation of a new concept of digital economy and digital management. Research results. The conditions of formation of the concept of digital economy and digital management in the conditions of new technological breakthroughs, on the basis of which the creation of a digital society is revealed. A new mission of digital economy and digital management is revealed, which should change the dominant essence of social philosophy, which underlies the great role of scientific and technological achievements that transform our reality. Conclusion - The formation of the concept of digital economy and digital management challenges many economic and (C) Cherep A. V. \& Andriukaitiene Regina \& Voronkova V. H. \& Oleksenko R. I., 2019
\end{abstract}


managerial notions of new technological breakthroughs that underpin the "boundaries of growth" and the formation of digital society.

Keywords: digital economy, digital management, digital society, digitalization, stochasticity of information

The problem of solvency in general and its contacts with important scientific or practical tasks.

Relevance of the research topic. The relevance of this topic is due to the fact that new processes of digitalization of society are unfolding in the conditions of new technological breakthroughs, which requires the formation of the concept of digital economy and digital management as components of the creation of an ecologically balanced and socially oriented economy, aimed at increasing the well-being of the population and improving the ecology of the population, and in the future on the emergence and development of digital society. The relevance of the study is that digital technologies today represent the most dynamic and innovative sphere of development that dominates in the world. This is facilitated by the new Digital Generation or Generation Z, which will work alongside robots and will not be surprised by the results of Big Data analysis - Big DATA, a generation that will not be surprised by crypto currencies or new block chain technologies, drones or drones. The rapidly evolving information and technology sphere shows that the digital world today is expanding at an incredible rate, and this applies to every sphere, every science, business, business, insurance, medicine, education [1].
The purpose of the study is to conceptualize the digital economy and digital management in the context of the new Industrial Revolution, Industry 4.0, as a factor in the emergence of an environmentally balanced and socially-oriented economy in the face of new technological breakthroughs, as one of the biggest challenges facing developed countries is sustainable unemployment, growing property inequality, rapid climate change and stochastic (asymmetric) information. The purpose of the study is to conceptualize digital technologies as the basis of a breakthrough in the technology industry, on which the competitiveness of states depends [2].

Formulating the goals of the article:

to reveal directions of development of digital technologies which promote development of technological branch;

- to formulate the concept of development of digital technologies as the basis of breakthrough technologies and directions of their digitalization.

An analysis of the latest research and publications that address this issue. In the works of Maxton Graham and Randers Joergen. "In search of prosperity. Managing Economic Development for Reducing Unemployment and Climate Change "(Kyiv: Pabulum, 2017) shows evidence of global natural resources being exhausted and of the limited

Formation of the concept of digital economy and digital management in the conditions of new technological breaks 
assimilation capacity of the planetary ecosystem. The revolutionary work of the new vision was the first report by the Roman Club "Limits of Growth" (1972) by Donnelly and Dennis Meadows and Jorgen Randers, which forced them to reflect on the physical limits of human growth. "The limits of growth. 30 Years Later" is an updated study based on new data on trends in the development of human civilization, improvements in the model and methodology of system dynamics and modern computer capabilities. We rely on the work of contemporary foreign authors such as Kelly Kevin, Eric Brinelfsson and Andrew McAfee, Regina Andriukaitiene, Martin Ford, Tim O'Reilly, Richard Florida, as well as authors such as M.Azhazha, M.Vishnevsky, P. Vodopianov, A. Sosnin, N. Kirichenko, A. Lazarevich, M. Maksimenyuk, V. Nikitenko, O. Kivlyuk, R. Oleksenko, O. Punchenko, N. Punchenko, V. Starzhinsky, V. Tsekalo, A. Cherep, A. Shevchenko, who in their works raised the problem of digital (information) technologies and their influence on the modern world.

The scientific novelty of the research is to identify the problems of interaction between the individual, society, information in the INDUSTRY 4.0 environment and the conditions for overcoming them, which contribute to the formation of a new concept of digital economy and digital management, and in the perspective of the digital society.

Research methodology is a systematic approach and modeling in the development of digital technologies, based on the methods of information, system and systemstructural analysis. It is hypothesized that digital technologies are emerging at the heart of the technology industry, which is being formed on the component of digitalization of the world, which penetrates into all spheres of human activity. Digital technologies are a major driver of human development, transforming entire industries and industries. The article argues that the digital society is evolving based on the development of digital technologies that bring change and promote successful entrepreneurship and business. Innovations have already come to our world and will change the world at an unprecedented speed, and this will affect every area and sector, which will in the future promote the development of smart society and smart technologies in the context of the development of modern civilization [3].

The scientific novelty of the study is that the digital field of research is as yet poorly understood in the sociophilosophical and economic literature. The result of the study is to formulate the concept of digital technologies as a basis for the breakthrough in the information technology industry and to outline ways of improving digital technologies and their implementation in all spheres of human life.

Selection of previously unknown parts of the general problem addressed in the article.

The technological revolution 4.0, which is evolving with incredible speed, has created a new digital world that has brought automation, robotics, 
artificial intelligence development, the development of new breakthrough technologies, which are commonly called nanotechnology, biotechnology, socio-humanitarian technology. The conditions of information society shape a digital society built on digital technologies that are commonly called digital, which shape the digital culture. The digital component in the aggregate is Digital Intellect, which is formed by the intellectual part of society, which is a priority in the development of the technological industry [4].

Outline of the main research material with justification of scientific results

We are trying to identify the conditions for shaping the concept of digital economy and digital management in the context of new technological breakthroughs, which underpin the creation of a digital society dominated by asymmetric information, and to open up a new mission of digital economy and digital management, which should change the dominance of social philosophy in the basis of which is the great role of scientific and technological achievements that transform our reality [5].

In today's information society, new types of digital economy are emerging (neo-economy, information economy, Internet economy, innovation economy, economy of the "knowledge society"), which require appropriate digital management and training of management elite as a creative class, formed on the basis of information, knowledge, intelligence, experience. The digital society consists of a large set of algorithms that control information and communications and computer technologies that penetrate digital management and form an information-oriented economy based on an intellectually creative component represented by human (intellectual) resources. One of the basic principles of modern neoeconomy is that new technological changes are a prerequisite for longterm economic growth. It was for this idea that Robert Merton Solow received the Nobel Prize in 1987 for "Fundamental Research in the Theory of Economic Growth" [6]. Direct management through digital technology makes a good manager even better. The digital economy causes the digitization of an increasing amount of information, goods and services, resulting in enormous improvements in telecommunications, increasing the role of networks and standards. Digital goods have a significantly lower marginal cost of production than physical goods; bits are cheaper than atoms, not to mention human labor. One manufacturer with a website can theoretically meet the needs of millions of customers. Thanks to technology, the digital world is created in which more products are produced with less use of resources such as raw materials, capital and labor [7]. All manifestations of technological advancement are based on digital technology, which is a powerful engine of growth and prosperity

Formation of the concept of digital economy and digital management in the conditions of new technological breaks 
(today the concept of computer prosperity has emerged). Perry believes that due to innovation and technology, all Americans (especially low- and middle-income groups) are now more affluent than in the previous period [8]. We are trying to prove that the average worker today is more affluent than his or her counterparts in previous generations because of the abundance brought about by innovation and technology. Many Americans believe that they are still alive in a land of opportunity that offers the greatest chance of economic development [9]. However, high levels of inequality can motivate people to work harder and boost overall economic growth. The prosperity of the country depends on innovation and it is not necessary to waste the innovative potential that will bring prosperity in the future. Today, we live in a world where machines are replacing humans, jobs and artificial intelligence are evolving, and the advent of robots and the development of robotics can threaten future unemployment. Automation is a threat to workers with low levels of education and low skills [10].

The analysis shows that the process of large-scale data dissemination (BIG DATA) owned by organizations is ongoing; a large number of new professions emerged; robotics. Today, we need to adapt to the potential effects of advanced technologies, and we may face the prospect of an "ideal storm" caused by digital technologies that have flooded the world (block chain, crypto currencies, fintech). Who knows what our future may be, but today the world needs to look with another eye, as it is a world of innovators, breakthrough technological ideas, the "coming of robots" and artificial intelligence, nanotechnology and biotechnology that compete with the human brain and require new mechanism of labor motivation [11].

The history of the computer era began when computers connected to phones. The effects of computerization began to develop from the 1980s, when computers connected to phones, resulting in the formation of a reasonable hybrid. It has been almost 40 years since then and the technological fusion of communications and computerization has intensified over this period, which has accelerated and gained widespread scope. The Internet and mobile technology systems have moved to the main stage of the modern technological sphere. The digital economy, which is based on these technologies, has experienced its ups and downs, formed under the influence of large-scale digital trends that have produced global historical trends, which will continue to maintain their momentum in the near future. "The brilliance of high-tech innovation is floating in slow currents. The roots of the digital world are expressed in physical needs and natural inclinations for bits, information and networks,"notes Kevin Kelly [7].

From digital technologies, the trends of the coming decades in the development of the digital world and digital culture are growing. Some traditional industries will disappear in the future, old business models will 
cease to exist, many professions will disappear, new professions will emerge, and the nature of digital technologies will shatter international borders. When we understand these changes, we will be able to work together with their nature, not against it. Virtual reality will become real and we will not be able to stop the processes of improving artificial intelligence and robots, creating new campaigns will become a daily reality. We must manage these digital processes in order to prevent not only present but also hypothetical disruptions and disruptive tendencies in their development [12].

We must cultivate and tame these inventions for the benefit of man. This is possible both legally and technologically with the help of our practical experience and our activity, since these technologies have already come into our lives, so changes are inevitable, because technologies are a catalyst for change. Anastasia Shevchenko's work says that "Technologies make our life comfortable. Easy-to-use, convenient and fast mobile applications and services allow you to get the services you need in minutes without getting out of the couch anywhere in the world where internet is available. I think that in the near future we will see the development of remote identification, biometric technologies, transactional products, continued migration of many spheres of life and services online "[33, p. 12].

In the future, technological life (sphere) will be a collection of endless updates: the pace of transitions accelerates, the characteristics shift, the default parameters disappear, one menu goes to another, etc. Digital technologies are demanding endless updates, the aging cycle of which is accelerating (the average life span of a mobile app or phone - some 30 days!). So there will be no time to reach mastery and professionalism in what will soon have to be written off. Technological innovations in digital technologies are pushing us to introduce the latest inventions, which will disappear over time as the next newest invention arrives and so we have to chase everything new and new [13].

Technology brings everlasting frustration that pushes for new and new inventions, so frustration drives digital ingenuity and digital advancement. "The current problems are the result of yesterday's technological successes, and the technological solutions to the current problems create the problems of tomorrow. This is a circular solution to problems and their solution leads to a stable accumulation over time,"notes Kevin Kelly [7, p.19].

Digital technologies as the basis for the breakthrough in the technology industry have led to the creation of artificial intelligence, which is the basis for the development of digital technologies and their improvement. Here are some examples of industries where the use of artificial intelligence is growing and becoming potentially productive: 1) intellectualized music; 2) intellectualized marketing; 3) intellectual construction; intellectualized ethics; 5) intellectual

Formation of the concept of digital economy and digital management in the conditions of new technological breaks 
toys; 6) intellectual sports, etc. Artificial intelligence has become an integral part of our daily lives, which today can perform various tasks - play chess, drive a car, and treat patients. Robots already have different shapes and different configurations, different sizes and functions that will go into workshops, factories and factories and will replace half the people [14].

Robotization will lead to automation that will create hundreds of millions of jobs in completely new industries that will enhance technological and technical progress. Baxter is one of the first models of industrial robots of the new class, created to help humans. He can look at the sides and at the same time change the position of his eyes to show what direction he is now looking. It's not as fast and accurate as other industrial robots, but it's smarter. In order to teach this robot, it is enough to take his hands and repeat the necessary movements in the desired sequence on the principle of "do as I do". Baxter gets acquainted with the procedure and then repeats it. Baxter is open to use. The main cost of an average robot - is not the cost of "iron" and operations. The cost of an industrial robot is close to $\$ 100,000$ and four times its programming, training and maintenance costs can be dispensed with [15]. Robots can be relied on in the physical and intellectual realms, but robots have already mastered some semantic processes better than physical ones. Thanks to computerized intelligence, robots can do what we never expected. The real revolution will begin then, with the code we will have at our disposal personal robots, such as Baxter [16].

The digital economy holds on to the free flow of copies. Products that are copied are software, music, movies, games that represent the global communications system. This service is improved much faster thanks to operating systems and is part of the technological breakthrough of the digital world. The Internet is a billion interconnected pages, on the basis of which information retention and active knowledge, the basic units today are streams of information from Twitter and Facebook, in the context of which we read blogs, bathe in the flow of information. There is no surplus of information in the digital age. Today we have switched to instant response mode. The basic units of the third digital world are streams, tags and webs in which digital information can be accessed in accordance with references [17].

If texts predominated in social networks, then the next generation of social networks of the digital era transmits video and sound. New tools are emerging that accelerate the flow of bits and copies. If the first revolution is the constant copying of a product so that it becomes a consumer product. The second revolution is the division of the product into parts; the product has evolved into a flow of services that are transmitted from the common web. It becomes a platform for enrichment and innovation. The third revolution is made possible by the first two, as streams of powerful services and ready-made items, at low cost, make it possible to create new products and completely new product 
categories. The steady trend towards dematerialization and decentralization means that flows become inevitable [18].

Over time, in the context of the digital society, mass circulation of books has changed the way people think, printing presses began to print books quickly, and the cultural power of books began to produce reproduction machines. Screen people began to ignore the classic logic of books and reverence for inexpensive copies of books. Books are digitally converted and can be spread on any screen at any time. The book turns from an artifact to a stream that floats on the screen and turns into a "process of being a book." Wikipedia is the first book-web, a web of connections, created by Collective Intelligence [19].

If books have helped to develop world-view thinking, then screens stimulate utilitarian thinking, read lightning and real-time thinking from the screen. Possession has lost its former value, and the access to information replaced it. Digital technologies have accelerated all these processes and stimulated the transition from products to services. Software becomes the first product to become a service [20].

Not so long ago another form of labor organization emerged - the platform. A platform is a foundation created by a firm that allows other firms to build their own services and products on its basis. A little later, a new generation of platforms emerged that had more features inherent in the markets and were, in fact, partly markets and partly firms. One such example is iTunes for iPhones. Apple owned this platform, which also became a marketplace for mobile applications. The generation of platforms has further expanded the power of the markets. The platform ecosystem is becoming a multilateral market, a prime example of which is Facebook [21].

Today, the most successful and richest organizations, strong ecosystems of interdependent markets and services like Apple, Microsoft, Google, Facebook. Ecosystems are governed by co-evolution, a biological dependency in which competition joins co-operation. Dematerialization, decentralization, and mass communications are contributing to the emergence of many platforms as service factories. Movies, books and games that we have access to live in the clouds, the Cloud is a colony of billions of computers that are intertwined as one and act as a large computer. These clouds, although invisible, lead our digital lives. The main reason to place something in the clouds is deep data sharing. There is no single architecture for them, so all its characteristics are constantly evolving. Today, all businesses and much of society depend on computers, and cloud computing makes it easier to justify a technology company. Being able to use the best infrastructure in terms of access to the cloud is the main reason why so many new companies have emerged in the Silicon Valley over the past 10 years. Over the next 30 years, the trend towards dematerialization,

Formation of the concept of digital economy and digital management in the conditions of new technological breaks 
decentralization, concurrency, and the use of platforms and clouds will continue [22].

As a result of technological breakthroughs related to the development of the Internet, the commercialization of the Internet, the distribution of open source software, the rebirth of the World Wide Web and the use of services have occurred. Technological innovations are breaking into our lives - services as requested. Networks, platforms and artificial intelligence are changing business, education, government, financial markets and the economy. Algorithm-driven global digital platforms are transforming our society [23].

The World Wide Web becomes a separate world. Provided reasonable display and processing of data, there are great opportunities and prospects for its further development. Apple has been generationally changing, from personal computer to smartphone and web to mobile applications. iPhone is the platform where advanced software is launched for the first time. After the death of Steve Jobs, Apple's innovation has slowed, but the company continues to be a leading player in the mobile phone market, and its original design solutions will continue to force us to "think differently" about the possibilities of a new technological future. Networking platforms are a powerful tool for shaping the next-generation economy, in which technologies create new kinds of work, built on creativity and innovation [24]. Formation of the concept of digital economy and digital management in the conditions of new technological breakthroughs includes the development of new models of economy, education, management:

1. In modern conditions new models of education, economy and management are being formed: digital education; digital economy (neoeconomics, Internet-economy); digital management; digital marketing. Therefore, modern catches require the preparation of new management elite, which is formed on the basis of information, knowledge, and intelligence [25].

2. Digital society requires a new concept of education and management, because traditional management is obsolete and modern consists of: a large set of algorithms that are driven by ideas and symbols; algorithms and technologies; organizations are governed by information and communication and computer technologies, based on the intellectual, creative and cognitive components. New information and computer technologies complement each other and form a new worldview and a new culture - information (digital), new competencies and behaviors, new expectations and aspirations [26].

3. Digital education and the digital economy require the development of new "breakthrough technologies": robotics; artificial intelligence; nano and biotechnology; sociohumanitarian technologies that contribute to the creation of new types of work and employment, and at the same time expand our capabilities. The world around is changing and brings with it automation, robotics and new business opportunities. The 
technology industry is the most dynamic in the world, which requires the development of the digital economy and digital management [27].

4. New education, new economy and new management are based on the creative component and the creative personality, which together constitute the "public intelligence" that accumulates in the intellectual part of society; form a creative class, which is a breakthrough in the development of society, that is, the creative economy is formed by the creative class, the essence of which is the creative era.

5. New (digital) education is stimulated by: the "innovation society"; "Smart-society" as highly intellectual; the digital age and digital technology; breakthrough technologies contribute to economic growth (computer well-being); serve as a catalyst for change [28].

6. Information and knowledge as the main productive resource of the digital economy (socioeconomics) is formed within the limits of networked Internet economy, intellectual economy of mind, cybernetic economy with electronic nervous system [29].

7. The essence of digitized transformations: the convergent paradigm of digital society is formed under the influence of fundamental universal civilizational transformations on a convergent basis, where convergence is an attribute of a higher level of evolution; relationships with a partner as a person; as with your like-minded person; partners' relations are formed regarding the "production" of information and knowledge, the multiplication of intellectual wealth, the mechanism of accumulation and realization of human and social capital; the subjects of the digital society do not absorb each other, but, mutually enriching, retain their originality, identical uniqueness, they remain on their own, which results in the convergent paradigm of the digital society [30].

8. The digital conception of the "human economy" is formed as a result of convergence on the basis of qualitative transformations of information mechanisms, network organization, organic synthesis of economic, social and digitized beginnings of the reproduction process; the convergence relationships of the digital society reflect the increasing potential of self-sufficiency of the human personality and act as the highest goal of digitalization, as the highest goal of harmonized sociality [31].

9. There is an increase in intellectual wealth, because knowledge and information are not alienated, the logic of competition and the logic of intellectual enrichment are combined, which leads to the interpenetration of creative beginnings and the formation of creative personality [32].

10. In the digital society, creative personality is in demand, so we must adapt to the potential consequences of the progressive development of technologies that are moving towards intellectualization and digitalization; without the help of the state, the

Formation of the concept of digital economy and digital management in the conditions of new technological breaks 
digital economy cannot become developed and socially oriented; smart technologies, smart education, smart culture, smart technologies that are the result of constant change should be developed; the concept of convergence in the information society has great energy potential.

Conclusions of the study and prospects for further exploration in this direction. Conclusion - The formation of the concept of digital economy and digital management challenges many economic and managerial notions of new technological challenges that underpin "growth boundaries". Creative capital acts as an integral beginning of the non-material factors of socioeconomic development, is formed on the basis of freedom, trust, creativity, which act as "spontaneous socialization", capable of self-expanding accumulation and self-reproduction. The digital economy is the economy of recreation and exchange of information, knowledge and social capital, the economy of human development as a creative personality, the digital economy, which is formed on the basis of network principles of Internet economy, synergetic principles and convergence.

\section{Prospects for further research}

- development of digital education and on its basis to form the concept of digital economy, digital society and digital management.

\section{REFERENCES}

1. Andriukaitiene, Regina, Voronkova, Valentyna, Kivliuk, Olga, Romanenko Tatyana and Ryzhova, Irina (2017). Konceptualizaciâ smart-society and smart-technologies in context development sovremennaya civilizacii. Mokslas ir praktika: aktualijos ir perspektyvos. 2017. P.11-12.

2. Jim, Al-Khalili. (2017). What Next? Even scientists can't predict the future - or can they? London: Profile Books, 248.

3. Bryjolfsson, Eric and McAfee, Andrew. (2014). The Second Machine Age: Work, Progress, and Prosperity in a Time of Brilliant Technologies. W.W.Norton Company, 236.

4. Voronkova, Valentina. The civil society as a paradigm, concept and social construct fhilosophical discourse. Philosophy and cosmology. Kyiv: ISPC, 2015 (vol.15). P.198-215.

5. Voronkova, Valentina and Kyvliuk, Olga (2017). Individual at the educational space of smart-society, Interdisciplinary Studies of Complex Systems.10-11, 88-95.

6. Voronkova, Valentina, Maksimenyuk, Marina and Nikitenko, Vitalina. (2016). Humanistic management in the context of phylosofic anthropology: human dimension. The new paradigm. Вип.129. 64-76.

7. Kevin, Kelly (2017). The Inevitable. Understanding the 12 Techological Forces That Will Shape Our Furure. NY Penguin Books, 304.

8. Maksimeniuk, M.Yu. and Nikitenko, V.O. (2016). Informational and communicative society as a kind of complex social systems and interaction. Humanitarian Bulletin of Zaporizhzhia State Engineering Academy, 66, 266-278.

9. Maxton, Graeme and Randers, Jorden (2016). Reinventing Prosperity. Managing Economic Growth to Reduce Unemployment, Inequality, and Climate Change. A Repport to the Club of Rome. Vancouver: Grestone Books, 320.

10. Meadowz, Donella, Randers, Jorders and Meadows, Dennis. (2006). Limits to Growth The 30-Year Update. London· Sterling VA. 464.

11. Melnyk, V.V. (2014). Hlobalizatsiia v kulturniy sferi: teoretyko-metodolohichnyi analiz. Hileia. 86. 219-225. 
12. Melnyk, V.V. (2011). The socio-philosophical analysis of the influence and interaction of individual and globalised society. Humanities bulletin of Zaporizhzhe state engineering academy. Issue 46. 96-108.

13. Nikitenko, V.O. (2013). Modern geokultura as a geokulturnij phenomenon. Humanitarian Bulletin of Zaporizhzhia State Engineering Academy.Issue 53. 261-270

14. Nikitenko, V.O. (2013). Problem field of the geokul' turnogo phenomenon: scientific approaches. Gileâ. Issue.71. 500-504.

15. Nikitenko, V.O. (2018). Education as a factor of creative personality establishment and development in information society. Humanities bulletin of Zaporizhzhe state engineering academy. Issue.74. 150-158.

16. Nikitenko, V. O. (2013). Geokulturni values in today's world development: a sociophilosophical dimension. Humanities Bulletin of Zaporizhzhe State Engineering Academy, 54, 266-280.

17. Nesterenko, J. K. and Cherep, A.V. (2005). Economic analysis of financial-economic activity of the enterprise: textbook. Guidances. K.: textbook literature.

18. Požhuêv, V.I. (2010). Making sense of the place and role of information in modern society. Humanities bulletin of Zaporizhzhia state engineering academy, 42, 4-13.

19. O' Reilly, Tim (2018) Who knows what will be the future. Lane. with the english Yulia Kuzmenko. K.: Our format, 448.

20. Ryzhova, I. (2011). Culture is the most fundamental way of human existence. Humanities Bulletin of Zaporizhzhe State Engineering Academy, 46, 126-134.

21. Rogers, E. M. (2009). Diffusion of innovations. Kyiv: Publishing House: KyivMohylian Academy, 591.

22. Christopher, S. (2018). Total automation. How computer algorithms change life. Kyiv: Our format, 280.

23. Starzhinsky, V. P. (2016). Towards an Innovation Society. Minsk: RIVSh, 446.

24. Fezerstoun, M., Lesh, S. and Robertson, R. (Eds.) (2013). Hlobalni modernosti. Kyiv: Nika-Tsentr, 400.

25. Floryda, R. (2018). «Homo creativus». Yak novyi klas zavoiovuie svit». Kyiv: Nash format, 432.

26. Ford, M. (2016). Engineering and the threat of the future. Kyiv: Our format, 400.

27. Fiurst, M., Yurhen, T. (2018). Filsoofiia. Kyiv: DUKh I LITERA, Instytut relihiinykh nauk sv. Fomy Akvinskoho, 544.

28. Chang, H.-J. (2018). 23 things they don't tell you about capitalism. Kyiv: Nash format, 296.

29. N. Katherine Hayles (1999). How We Became Posthuman. Virtual Bodies in Cybernetics, Literature, and Informatics. Chicago London The University of Chicago Press, 426.

30. Cherep, A.V. (2007). Control the cost of the subject of management. Part 1: monograph. Zaporizhzhia.

31. Cherep, A.V. and Lazneva, I. O. (2005). Methods of cost management of production and their comparative analysis. Forming market relations in Ukraine: a history, 11, 67-72.

32. Cherep, A.V., Cherep, O.H., Krylov, D.V. and Voronkova, V. H.. Methodological approach to the redistribution of investment projects within a company According to formal criteria. Financial and credit activity-problems of theory and practice. Volume 28, Issue 1. 2019. p. 256-263

DOI: https://doi.org/10.18371/fcaptp.v1i28.163991

33. Shevchenko, A. (2018). Digital era. Just about digital technology. Kyiv: Summit Book, 457.

Formation of the concept of digital economy and digital management in the conditions of new technological breaks 
Череп, А. В. - доктор економічних наук, професор, декан факультету економіки, Заслужений діяч науки і техніки України, Академік наук вищої освіти України, Запорізький національний університет (Запоріжжя, Україна)

E-mail: cherep.av.znu@gmail.com, ORCID iD : 0000-0001-5253-7481

Андрюкайтене, Регіна - доктор $\mathrm{PhD}$ соціальних наук (менеджмент), доцент, зав. кафедри бізнесу та економіки, Маріямпольська колегія (Маріямполе, Литва), лектор Литовського університету спорту (Каунас, Литва)

E-mail: regina.andriukaitiene@gmail.com, ORCID iD : 0000-0002-0691-7333

Воронкова, В. Г. - доктор філософських наук, професор, завідувач кафедри менеджменту організацій та управління проектами, Інженерний інститут Запорзького національного університету (Запоріжжя, Україна)

E-mail: valentinavoronkova236@gmail.com, ORCID iD : 0000-0002-0719-1546

Олексенко, Р. I. - доктор філософських наук, професор, професор кафедри публічного управління та права, Таврійський державний агротехнологічний університет (Мелітополь, Україна)

E-mail: roman.xdsl@ukr.net, ORCID iD : 0000-0002-2171-514X

\section{ФОРМУВАННЯ КОНЦЕПЦІЇ ЦИФРОВОЇ ЕКОНОМІКИ І ЦИФРОВОГО МЕНЕДЖМЕНТУ В УМОВАХ НОВИХ ТЕХНОЛОГІЧНИХ ПРОРИВІВ}

Анотація. Актуальність даної теми зумовлена тим, що нові процеси інформатизації суспільства розгортаються в умовах нових технологічних проривів, що вимагає формування концепції цифрової економіки і цифрового менеджменту як складових чинників створення екологічно збалансованої і соціально-орієнтованої економіки, яка націлена на збільшення добробуту населення та покращення екологічного показника. Мета дослідження -- концептуалізація цифрової економіки і цифрового менеджменту в умовах нових технологічних проривів як чинника становлення екологічно збалансованої і соціально-орієнтованої економіки, так як одним 3 найбільших викликів, що стоять перед розвиненими країнами, $\epsilon$ стале безробіття, зростаюча майнова нерівність, стрімкі зміни клімату та схоластичність (асиметричність) інформації. Аналіз останніх досліджень і публікацій, в яких започатковано розв'язання даної проблеми. В роботах Макстон Грема і Рандерс Йоргена. «У пошуках добробуту. Керування економічним розвитком для зменшення безробіття та змін клімату» (Київ: Пабулум, 2017).У другій половині XX ст. з'явилися свідчення вичерпності глобальних природних ресурсів та обмеженості асимілюючих можливостей планетарної екосистеми. Революційною працею нового бачення стала перша доповідь Римському клубу «Межі зростання» (1972р.) Донелли та Деніса Медоузів і Йоргена Рандерса, які примусили замислитеся над фізичними межами економічного зростання людства. «Межі зростання. 30 років потому» - оновлене дослідження, що базується на нових даних про тенденції розвитку людської цивілізації, удосконалення моделі й методології системної динаміки та сучасних комп'ютерних можливостей. Наукова новизна дослідження - виявлення проблем взаємодії людини, суспільства, інформації в умовах нових технологічних проривів та умови подолання проблем стохастичності інформації, що сприяють формуванню нової концепції цифрової економіки і цифрового менеджменту. Результати дослідження. Виявлено умови формування концепції цифрової економіки і цифрового менеджменту в умовах нових технологічних проривів, в основі яких створення цифрового суспільства. Розкрито нову місію цифрової економіки та цифрового менеджменту, завдяки яким має відбутися зміна домінантної сутності соціальної філософії, в основі якої велика роль науково-технічних досягнень, що трансформують нашу реальність. Висновок формування концепції цифрової економіки і цифрового менеджменту кидає виклик

(C) Cherep A. V. \& Andriukaitiene Regina \& Voronkova V. H. \& Oleksenko R. I., 2019 
багатьом економічним та управлінським поняттям нових технологічних проривів, в основі яких «межі зростання» і формування цифрового суспільства.

Ключові слова: цифрова економіка, цифровий менеджмент, цифрове суспільство, діджиталізація, стохастичність інформації

Череп, А. В. - доктор экономических наук, профессор, Заслуженный деятель науки и техники Украины, Академик Академии наук высшего образования Украины, декан факультета экономики, Запорожский национальный университет (Запорожье, Украина)

E-mail: cherep.av.znu@gmail.com, ORCID iD : 0000-0001-5253-7481

Андрюкайтене, Регина - доктор $\mathrm{PhD}$ социальных наук (менеджмент), доцент, зав. кафедрой бизнеса и экономики, Мариямпольская коллегия (Мариямполь, Литва), лектор Литовского университета спорта (Каунас, Литва)

E-mail: regina.andriukaitiene @ gmail.com, ORCID iD : 0000-0002-0691-7333

Воронкова, В. Г. - доктор философских наук, профессор, заведующая кафедрой менеджмента организаций и управления проектами, Инженерный институт Запорожского национального университета (Запорожье, Украина)

E-mail: valentinavoronkova236@gmail.com, ORCID iD : 0000-0002-0719-1546

Олексенко, Р. И.- доктор философских наук, профессор, профессор кафедры публичного управления и права, Таврический государственный агротехнологический университет (Мелитополь, Украина)

E-mail: roman.xds1@ukr.net, ORCID iD : 0000-0002-2171-514X

\section{ФОРМИРОВАНИЕ КОНЦЕПЦИИ ЦИФРОВОЙ ЭКОНОМИКИ И ЦИФРОВОГО МЕНЕДЖМЕНТА В УСЛОВИЯХ НОВЫХ ТЕХНОЛОГИЧЕСКИХ ПРОРЫВОВ}

Аннотация. Актуальность данной темы обусловлена тем, что новые процессы цифровизации общества разворачиваются в новых условиях технологических прорывов, которые требует формирования концепции цифровой экономики и цифрового менеджмента как составляющих факторов создания экологически сбалансированной и социально-ориентированной экономики, которая нацелена на увеличение благосостояния населения и улучшение экологического показателя. Цель исследования - концептуализация цифровой экономики и цифрового менеджмента в условиях новых технологических прорывов как фактора становления экологически сбалансированной и социально-ориентированной экономики в условиях новых технологических прорывов, так как одним из наибольших вызовов, которые стоят перед развитыми странами, есть устойчивая безработица, увеличивающееся имущественное неравенство, стремительные изменения климата и с тохастичность (ассиметричность) информации. Анализ последних исследований и публикаций, в которых начато рассмотрение данной проблемы. В работах Макстон Грема и Рандерс Йоргена. «В поисках благосостояния. Управление экономическим развитием для уменьшения безработицы и изменений климата» (Киев: Пабулум, 2017). Во второй половине XX ст. появились свидетельства исчерпания глобальных природных ресурисов и ограниченности ассимилированных возможностей планетарной экосистемы. Революционным трудом нового видения считается первый докдла Римскому клубу «Границы роста» (1972) Донеллы и Дениса Йоргена Рандерса, которые заставили задуматься над физическими границами экономического роста человечества. «Границы увеличения. 30 лет после» - обновленное исселедование, которое базируется на новых данных о теннденциях развития человеческой цивилизации, усовершенствовании модели и методологии системной динамики и современных Formation of the concept of digital economy and digital management in the conditions of new technological breaks 
компьютерных возможностей. Научная новизна исследования - выявление проблем взаимодействия человека, общества, информации в условиях новых технологических прорывов и условия преодоления проблем стохастичности и нформации, которые содействуют формированию новой концепции цифровой экономики и цифрового менеджмента. Результаты исследования. Выявлены условия формирования концепции цифровой экономики и цифрового менеджента в условиях новых технологических прорывов, в основе которой создание цифрового общества. Раскрыта новая миссия цифровой экономики и цифрового менеджмента, благодаря которым должно произойти изменение доминантной сущности социальной философии, в основе которой большая роль научно-технических достижений, которые трансформируют нашу реальность. Вывод - формирование концепции цифровой экономики и цифрового менеджмента бросает вызов многим экономическим и управленческим понятиям технологических прорывов, в основе которых «границы роста» и формирование цифрового общества.

Ключевые слова: цифровая экономика, цифровой менеджмент, цифровое общество, диджитализация, стохастичность информации

Стаття рекомендована до публікаиії д.філос.н., проф. О.П.Кивлюк (Київ, Україна) Надійшла до редколегії: 07.06.2019 p. Прийнята до друку: 17.06.2019 р. 